\title{
The assessment of the impact of the chosen exploational conditions of hydraulic arrangement on the working liquid condition
}

\author{
Joanna Wilczarska ${ }^{1, *}$, Ewa Kuliś1 ${ }^{1}$, Marcin Łukasiewicz ${ }^{1}$, Eukasz Fornal ${ }^{2}$, Natalia \\ Dluhunovych $^{3}$ \\ ${ }^{1}$ Department of Vehicle Engineering, UTP Bydgoszcz, Poland \\ ${ }^{2}$ Stanisława Staszic State Higher School of Vocational Education in Pila, Poland \\ ${ }^{3}$ Faculty of Programming Computer and Telecommunication System, Khmelnytsky National \\ University, Ukraine
}

\begin{abstract}
Hydraulic systems in modern vehicles and agricultural machines have many components. In order to achieve high efficiency of the system, the system requires an accurate filtration system that allows you to reduce the amount of contaminants. Therefore, an important aspect is to determine the content of impurities in the working liquid, so we can diagnose and then predict the durability of the entire hydraulic system. This paper presents selected methods and means of state assessment, as well as the methodology for testing the working fluid. The results of experimental studies conducted in accordance with the developed methodology have been presented, which made it possible to obtain an appropriate analysis of results and draw appropriate conclusions. The results of the research confirmed the validity of the research activities undertaken using the passive experiment.
\end{abstract}

\section{Introduction}

Operating conditions may affect the functioning of hydraulic systems in vehicles and working machines. The quality of use, maintenance and storage influence this aspects. Currently, most vehicles and working machines have extensive hydraulic systems. This has a direct effect on the amount of working liquid in the hydraulic system. The costs associated with the replacement of the hydraulic energy medium are large. Modern hydraulic systems require high efficiency with relatively small dimensions. That is why manufacturers of hydraulic system components, to meet the customer's needs they perform elements with smaller and smaller fits of cooperating elements, which is associated with better quality of the working liquid and its purity. In addition to the very precise system of filtration, this warrants the need to determine changes in selected properties of working fluids - even in the aspect of their use [4,14].

\subsection{Analysis of methods and means for assessing the state of the working fluid}

For the functioning of hydraulic systems, the condition of the working liquid is very important. During operating the hydraulic system, the quality of the oil generally deteriorates - a phenomenon known as degradation. It was determined that $70-80 \%$ of failures of hydraulic systems result from the contamination of the working medium. Therefore, it is necessary to control the parameters determining the hydraulic factor, which have a serious impact on the change of physical properties, but also utility properties $[2,3,6]$.

\footnotetext{
*Corresponding author: asiulazol@utp.edu.pl
} 
The most commonly used methods for assessing the working fluid state include:

a) organoleptic methods - these are the methods that evaluate the state of the working medium by means of human senses,

b) instrument methods (the most frequently used instruments are [5]: - hydrometer for determining the density of liquids, laboratory scale, viscometer),

c) laboratory methods - these are the methods that use appropriate chemical reactions that allow you to determine the appropriate states of the working fluid. Examples of chemical reactions include [7,8]: - distillation; - crystallization; - sorption, etc.

Depending on the tested parameter of the working fluid state, the following measures can be determined:

a) color and transparency $[8,9,10]$ :

- dark color indicates aging of the agent during operation and too long time of use, additionally, milky precipitation indicates the water in the working medium,

- Lovibond method - it functions by applying patterns that can be applied to each other to create a palette of colors ;

- Stammer type colorimeter - using the standard filters, the illuminated liquid column is compared until the same color as the standard is obtained.

b) means for determining the content of solid contaminants $[2,9]$ :

- microscopic methods consist of filtering a proper amount of working liquid through a specific membrane filter with a grid, in order to calculate the amount of solid particles. It allows to determine their quantity, and to group the particles in terms of size, shape and color;

- colmatage meter - it is a device based on the relationship between the pressure difference of the working liquid and the size of the gap, the flow rate of the liquid and the content of particles with dimensions greater than the dimensions of the gap. They are used in precision systems in which continuous monitoring of the working fluid condition is required;

- particle counters are equipped with photoelectric sensors to determine the degree of contamination from the flowing liquid. In addition, the analyzed data is presented in the appropriate purity class according to ISO standards 4406:1999, NAS 1638 or SAE AS 4059. This type of devices allow quick and continuous monitoring of changes occurring in the hydraulic system.

c) means for determining the water content [9]:

- Karl Fischer's method consists in mixing the right amount of oil and two reagents in a closed chamber. The hydrogen produced from the water in oil allows to determine its content;

- Dean-Stark method relies on the distillation of water from the working medium to the receiver, which has a measuring scale to read;

- capacitive transducers enable not only continuous measurement of water content in oil, but also its temperature. Saturated water affects the sensor signal, which allows obtaining measurement results;

d) the kinematic viscosity determined by means of the capillary viscometer consists of measuring the time of flow of the working fluid from one capillary reservoir to the other ;

e) means to determine the acid number and the basic number [11]:

- titration of the weighed amount of the test liquid in a well-defined solvent with an appropriate indicator;

- comparison of the measuring potential of the indicator electrode to the non-polarizing electrode immersed in the tested working liquid;

f) means to determine the content of elements $[9,12]$ : 
- spectrometry generally involves examining the electron spectra of chemical compounds in a liquid working molecule, followed by comparison with the standard spectra.

- the activation analysis consists of measuring the radiation of the nuclear isotope formed in the sample. This allows to determine the amount of traces of metallic elements on the surface of the working liquid;

- the colorimetry is used to determine the concentration of the liquid based on the intensity of the color of the chemical compounds as compared to the standard factor. Photocell allows to determine content of some elements and organic substances;

- polarography is based on the registration of changes in the intensity of current flowing through the electrolytic vessel depending on the voltage on the mercury electrode or a constant. It is used to determine the content of elements such as: sulfur, nitrogen, oxygen, etc.

g) the ability to separate water is carried out under static conditions that are relevant to the operating conditions of the spray liquid;

h) the tendency to foam is determined by the volume of foam. The test sample is placed in a measuring cylinder and aerated for a suitable time. Then, in the meantime, the volume amount of foam is determined $[5,9,10]$;

i) the electric breakdown resistance consists in determining the voltage at which the electric spark passes through the liquid sample under test $[8,10]$;

j) ignition temperature - the principle of determining this parameter consists of heating up the tested oil until the generated vapours mixed with air create a combustible or explosive mixture. In this methods we used apparatus with an open crucible (e.g. Cleveland) or a closed crucible (e.g. Martens-Pensky) [13];

k) coking residues - the parameter is determined by two methods, e.g. Conradson and Ramsbottom. Both methods have a similar principle of operation, - where the liquid at high temperature, without access to air, transforms into a residue in the form of coke. The mass is weighed and expressed in \% in relation to the mass of the medium to be treated $[5,7,8,9]$.

\section{Methodology for assessing the working fluid condition}

\subsection{Determining the operating conditions of hydraulic systems}

According to the definition, the operating conditions of technical facilities are divided into terms of use, maintenance and storage.

Due to the conditions of use of the hydraulic system, conditions [11,12] can be distinguished as: light, medium and heavy.

Due to the operating conditions of the hydraulic system, it is possible to distinguish between the following types [13]:

- extreme - these are the activities performed as a last resort such as, supplying the system with any working fluid and performing repairs of the largest damage to the object directly affecting the start-up of this device system;

- correct - these are the activities that allow to maintain the fitness condition of the task system, while all other elements remain without significant service;

- proper - these are the activities supporting the entire facility in the state of fitness in terms of task and function. This type of technical object is ready for any random events regardless of time and place.

Due to the method of storage of the hydraulic system, the following forms can be distinguished:

- bad - the system is exposed directly to weather conditions throughout its lifetime.

- good - the system is secured appropriately. The whole object is located in a drained room, ensuring the limitation of all or a large part of the atmospheric factors that affect its aging. 


\subsection{Set of working liquid parameters determination}

Following the discussion above, the following features of the state, i.e. solid impurities content in the working liquid and water content in the working liquid, require further investigation.

The parameter describing the amount of impurities in the tested hydraulic oil will be the parameter referring to the oil purity classes determined using the instrument method.

The parameter describing the amount of water in the tested hydraulic oil will be the percentage of water content.

The scope of the assessment of the condition of the spray liquid, in accordance with specific sets of state characteristics and diagnostic parameters, will refer to oil contamination with solid particles and water content. The following conditions for the assessment of the status of the subject status were adopted by measuring the determined parameters [14]:

a) Oil samples for testing should show the actual state of the entire working medium. Samples for testing should be taken directly during the system operation or when the system stops, within a time not exceeding 15 minutes (the oil temperature should correspond to the recommended temperature specified by the equipment manufacturer).

b) You should take samples from the same place, which allows better interpretation of the results and eliminate measurement error.

c) Ensure cleanliness while collecting the sample and the vessel itself, which should be clean and dry.

d) The method of sampling is determined by the appropriate standard.

e) If the system does not allow to take a sample from the pipe, it can be taken from the tank using a suitable device.

f) The appropriate frequency of sampling should be considered.

The purpose of the assessment of condition of the working liquid is to determine the water content and solid contaminants in the hydraulic oil.

a) The purity class parameter should be used to determine the solid impurity content. Due to the minimization of the dimensions of the elements and to increase the efficiency of the system, it performs tribological systems with smaller and smaller fitting tolerances, which translates directly into the purity of the oil used. Therefore, it is required to deliver and introduce clean liquid to the cleaned system, as well as effective filtration and control of the cleanliness of the liquid during the operation of the system. Thanks to the cleanliness class, you can determine the quality of the hydraulic system operating fluid. The most commonly used standards for determining the purity classes are ISO 4406: 1999 and NAS 1638. It could be determined their number depending on the size and amount of working liquid.

b) The percentage of water content should be used to determine the water content in the spray liquid. An important point is the saturation point of the oil, in which the oil can not take more water and is determined by the value of $100 \%$. Value up to $100 \%$ - suggests dissolved water, i.e. a small amount of water is absorbed into the chemical composition of the spray liquid, which allows the drainage of water from the system without any consequences. However, the value above $100 \%$ - suggests undissolved water, the amount of which exceeds the value of water that it can absorb in its composition, which is visible in the form of water precipitates (emulsions). Most currently used working fluids in modern hydraulic systems have a saturation level below 50\%. This value prevents the corrosion of system components and the loss of oil properties. [1,3,5]. 


\section{Evaluation of the impact of selected operating conditions of the hydraulic system on the working fluid condition}

\subsection{Research object}

The object of the current research was hydraulic oil used in three hydraulic systems of agricultural machines. Hydraulic oils from 3 agricultural machines, namely 2 farm tractors fed with the same oil grade and a telehandler fed with a second oil grade were used for the tests. The first test object was oil from the Claas Axion 830 agricultural tractor hydraulic system from 2015 year production (fig. .1). The tractor has combined transmission and hydraulics arragements. The object is used on a farm only in transportation activities. Another object of the research was hydraulic oil from the Claas Xerion 5000 agricultural tractor from 2012 year production (fig. 2). The tractor has a separate hydraulic system, which means that hydraulic oil is used only in this system. The object works on a farm only in field works.

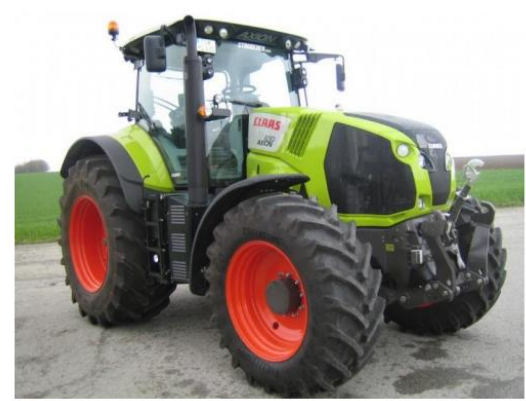

Fig. 1. Agricultural tractor Claas Axion 830.

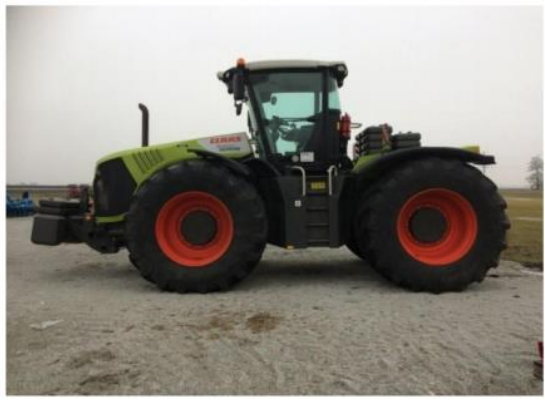

Fig. 2. Agricultural tractor Claas Xerion 5000.

In the presented Claas farm tractors, hydraulic oil CLAAS AGRIHYD HVLP-D46 is used. It is a mineral hydraulic oil with inhibitors of oxidation and corrosion, anti-wear additives and viscosity additives, with the following parameters:

$\begin{array}{lll}\text { density at } 15^{\circ} \mathrm{C} & - & 0,874 \mathrm{~kg} / \mathrm{dm}^{3} \text {; } \\ \text { kinematic viscosity at } 40^{\circ} \mathrm{C} & - & 45 \mathrm{~mm}^{2} / \mathrm{s}(\mathrm{cSt}) \\ \text { kinematic viscosity at } 100^{\circ} \mathrm{C} & - & 8,4 \mathrm{~mm}^{2} / \mathrm{s}(\mathrm{cSt}) ; \\ \text { viscosity index } & - & 166 ; \\ \text { flow temperature } & - & 33^{\circ} \mathrm{C} .\end{array}$

Another object of the study was the hydraulic oil from the JCB 535-95 telehandler from 2009 (fig. 3). The loader has a separate hydraulic system. The object is used on farms only for animal production and alongside other milk production machines .

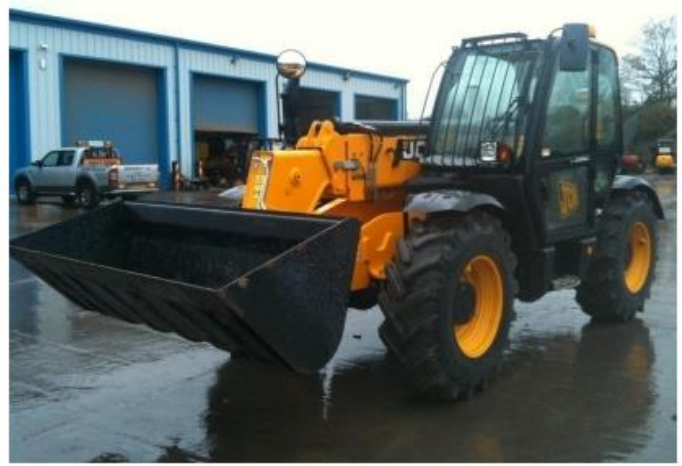

Fig. 3. Telescopic loader JCB 535-95 
The JCB telescopic loader uses JCB hydraulic oil: JCB HYDRAULIC FLUID HP 46. It is a mineral hydraulic oil based on zinc technology and on a refined soluble oil base and the following parameters:

density at $15^{\circ} \mathrm{C}$

kinematic viscosity at $40^{\circ} \mathrm{C}$

kinematic viscosity at $100^{\circ} \mathrm{C}$

viscosity index

flow temperature

$\begin{array}{ll}- & 0,872 \mathrm{~kg} / \mathrm{dm}^{3} \\ \text { - } & 46 \mathrm{~mm}^{2} / \mathrm{s}(\mathrm{cSt}) \\ \text { - } & 7,9 \mathrm{~mm}^{2} / \mathrm{s}(\mathrm{cSt}) \\ - & 143 \\ \text { - } & 39^{\circ} \mathrm{C}\end{array}$

\subsection{Research tools}

For the tests, the measuring instrument HYDAC FCU 1000 was used. The apparatus ensured the determination of the solid contamination content, the percentage water content and the temperature in the essence of the mineral working liquid. It is a portable device that, with the help of appropriate hydraulic connections, enables its use in the control and supply circuit of the hydraulic system [15]. Technical specifications of the device:

- particle counter (optical method) determining the size and amount of solid particles;

- capacitive-resistive transducer defining the percentage of water and temperature of the liquid;

- intended for hydraulic oils $10 \ldots 350 \mathrm{~mm} 2 / \mathrm{s} / 16 \ldots 1622 \mathrm{Sus}$;

- determination of cleanliness classes according to the following standards: ISO 4406:1999; NAS 1638 and SAE AS 4059;

- accuracy of measurement by code +/- 0,5 ISO;

- supply voltage $24 \mathrm{~V}$ DC;

- working pressure: 45bar/max. 650 psi (without adapter); 345 bar/max. 5000 psi (with adapter); 0 bar (from the tank);

- pump for automatic control of the working fluid flow [15].

\subsection{Workplace tests and analysis of test results}

The tests were carried out on farms, in the region of Złotów and in the Pila, from August 2016 to June 2017. Operating conditions were deliberately varied to allow for differentiated results. In addition, each object has only one operator. At the beginning of the assessment of the impact of selected operating conditions of the hydraulic system on the condition of the working fluid, messages were obtained about hydraulic oils used in the facilities, i.e. their detailed specification. It was determined that samples for testing hydraulic oils would be collected using sterile, disposable surgical instruments every 50 hours. Samples were collected using laboratory syringes and using a suitable hydraulic conduit. Then, 10 measurements were taken from each sample under laboratory conditions (at $20^{\circ} \mathrm{C}$ ), to determine the oil cleanliness class according to ISO 4406: 1999 and NAS 1638, as well as the percentage water content. After the tests, the oil tested was returned for re-use of the hydraulic system - according to the instructions of HYDAC FCU 1000 [10,14]. Table 1 presents the general operating conditions under which agricultural vehicles and machines were used, maintained and stored at the time of sampling.

Table 1. Information on the operational conditions of vehicles and agricultural machinery.

\begin{tabular}{|c|c|c|c|}
\hline $\begin{array}{c}\text { Operating } \\
\text { conditions: }\end{array}$ & Claas Axion 830 & Claas Xerion 5000 & JCB 535-95 \\
\hline use & medium & medium & heavy \\
\hline maintenance & propper & propper & correct \\
\hline storage & good & dood & bad \\
\hline
\end{tabular}


The tables and graphs below present the results of research related to the number of solid particles and the percentage of water in oil. In addition, all values related to the liquid purity class have been included.

Table 2. Results of hydraulic tests of agricultural tractor Claas Axion 830 in terms of the condition of the spray liquid, and the course of work - Pearson's correlation coefficient.

\begin{tabular}{|c|c|c|c|c|c|}
\hline No & $\begin{array}{c}\text { Workflow } \\
\text { [mth] }\end{array}$ & $\begin{array}{l}\text { Average amount of } \\
\text { particles }>4 \mu \mathrm{m} \\
\text { according to the } \\
\text { ISO standard }\end{array}$ & $\begin{array}{l}\text { Average amount of } \\
\text { particles }>2 \mu \mathrm{m} \\
\text { according to the } \\
\text { NAS standard }\end{array}$ & & $\begin{array}{l}\text { erage } \\
\text { entage of } \\
r \text { content } \\
{[\%]}\end{array}$ \\
\hline 1 & 3020 & 6000000 & 4498696 & & 21,2 \\
\hline 2 & 3069 & 6000000 & 5278212 & & 20,7 \\
\hline 3 & 3122 & 6000000 & 3745344 & & 20,6 \\
\hline 4 & 3171 & 6000000 & 4653944 & & 20,0 \\
\hline 5 & 3219 & 3000000 & 3032132 & & 19,8 \\
\hline 6 & 3268 & 3000000 & 2899232 & & 19,9 \\
\hline 7 & 3320 & 3000000 & 4379032 & & 21,2 \\
\hline 8 & 3372 & 3000000 & 3554868 & & 23,6 \\
\hline 9 & 3417 & 3000000 & 5681520 & & 25,5 \\
\hline 10 & 3470 & 3000000 & 5604796 & & 28,3 \\
\hline \multirow{2}{*}{\multicolumn{2}{|c|}{$\begin{array}{l}\text { Pearson's } \\
\text { correlation } \\
\text { coefficient }\end{array}$}} & \multicolumn{2}{|c|}{$\begin{array}{c}\text { Dependence between the course of the } \\
\text { object's operation and the amount of solid } \\
\text { particles }>2 \mu \mathrm{m} \text { according to the NAS } \\
\text { standard }\end{array}$} & .20 & $\begin{array}{c}\text { Weak } \\
\text { correlation }\end{array}$ \\
\hline & & \multicolumn{2}{|c|}{$\begin{array}{l}\text { The dependence between the course of the } \\
\text { object's operation and the percentage of water } \\
\text { content. }\end{array}$} & .75 & $\begin{array}{l}\text { Very high } \\
\text { correlation }\end{array}$ \\
\hline
\end{tabular}

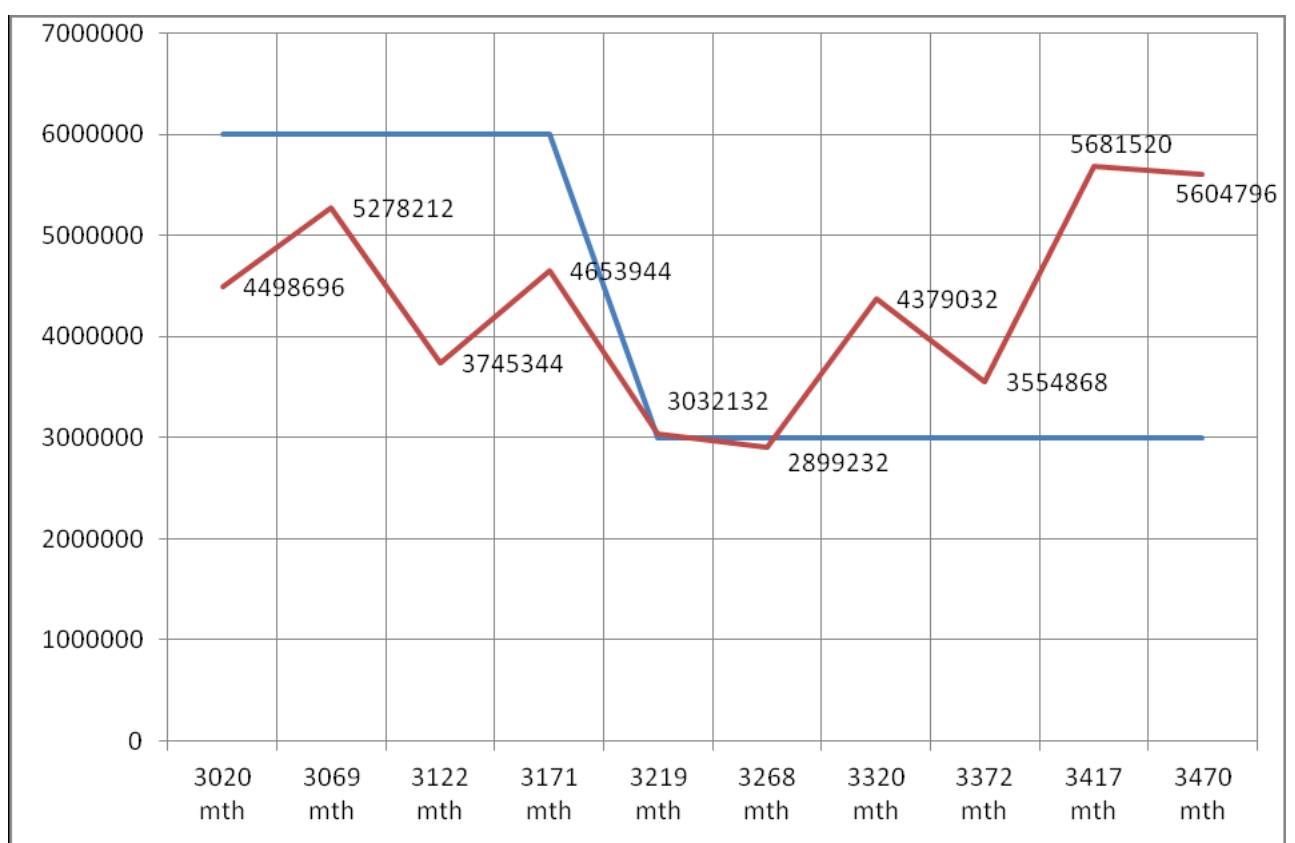

Fig. 4 The graph shows the number of solid particles in oil according to ISO 4406: 1999 and NAS 1638 in relation to the work progress of the Claas Axion 830 farm tractor. Blue line - Average amount of particles $>4 \mu \mathrm{m}$ according to the ISO standard. Red line - summed average number of solid particles above $2 \mathrm{~mm}$ in size according to NAS standard. 


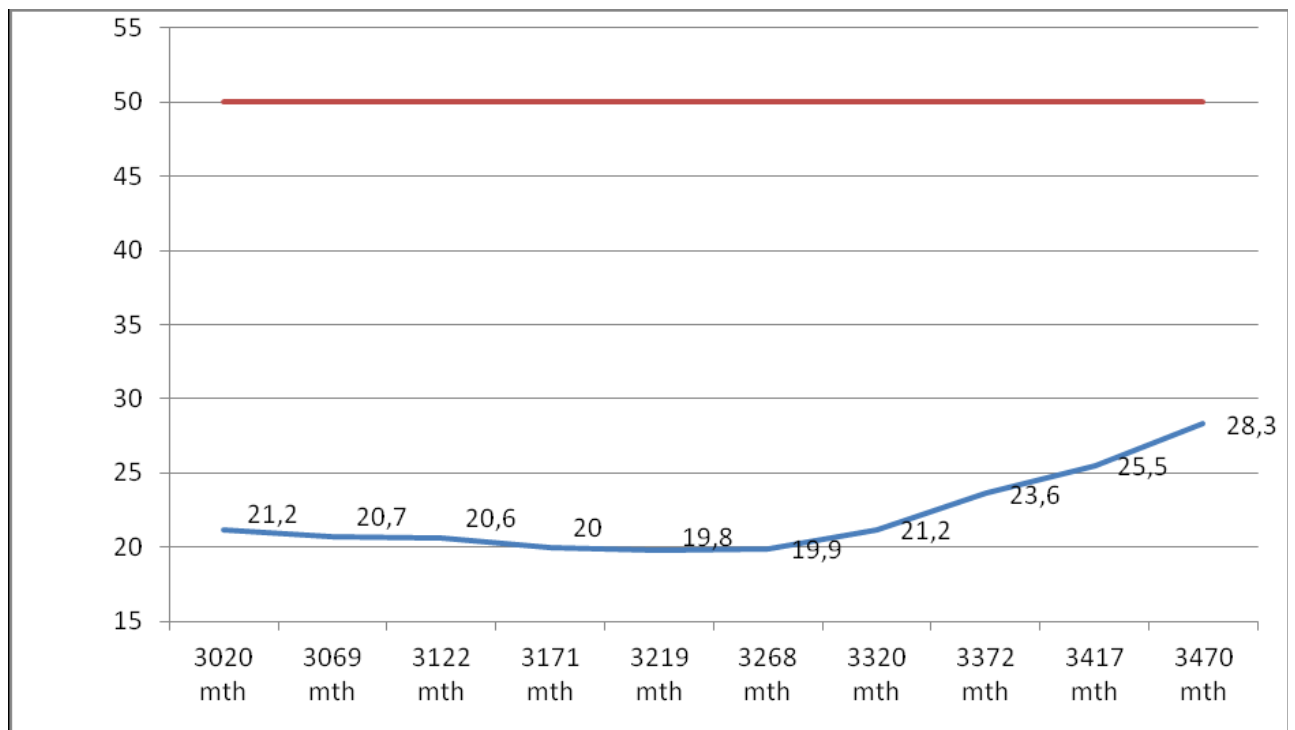

Fig. 5. Presentation of the percentage of water in oil in relation to the safe level of saturation and work progress of the agricultural tractor Claas Axion 830. Blue line - average percentage of water content [\%]. Red line - safe level of water saturation in oil (less than $50 \%$ ).

Table 3. Results of hydraulic tests of agricultural tractor Claas Xerion 5000 in terms of the condition of the spray liquid, and the course of work - Pearson's correlation coefficient.

\begin{tabular}{|c|c|c|c|c|c|}
\hline No & $\begin{array}{c}\text { Workflow } \\
\text { [mth] }\end{array}$ & $\begin{array}{l}\text { Average amount of } \\
\text { particles }>4 \mu \mathrm{m} \\
\text { according to the } \\
\text { ISO standard } \\
\end{array}$ & $\begin{array}{l}\text { Average amount of } \\
\text { particles }>2 \mu \mathrm{m} \\
\text { according to the } \\
\text { NAS standard } \\
\end{array}$ & & $\begin{array}{l}\text { verage } \\
\text { eentage of } \\
\text { er content } \\
{[\%]}\end{array}$ \\
\hline 1 & 1509 & 750000 & 287478 & & 22,2 \\
\hline 2 & 1561 & 750000 & 486868 & & 24,5 \\
\hline 3 & 1610 & 1500000 & 771804 & & 28,7 \\
\hline 4 & 1662 & 1500000 & 1679772 & & 32,6 \\
\hline 5 & 1708 & 1500000 & 1860880 & & 37,0 \\
\hline 6 & 1758 & 3000000 & 2375376 & & 40,7 \\
\hline 7 & 1812 & 3000000 & 2515554 & & 42,8 \\
\hline 8 & 1864 & 1500000 & 1988732 & & 43,2 \\
\hline 9 & 1910 & 750000 & 1896948 & & 44,4 \\
\hline 10 & 1960 & 1500000 & 2310776 & & 45,6 \\
\hline \multirow{2}{*}{\multicolumn{2}{|c|}{$\begin{array}{l}\text { Pearson's } \\
\text { correlation } \\
\text { coefficient }\end{array}$}} & \multicolumn{2}{|c|}{$\begin{array}{c}\text { Dependence between the course of the } \\
\text { object's operation and the amount of solid } \\
\text { particles }>2 \mu \mathrm{m} \text { according to the NAS } \\
\text { standard }\end{array}$} & .84 & $\begin{array}{l}\text { Very high } \\
\text { correlation }\end{array}$ \\
\hline & & \multicolumn{2}{|c|}{$\begin{array}{l}\text { The dependence between the course of the } \\
\text { object's operation and the percentage of water } \\
\text { content. }\end{array}$} & .97 & $\begin{array}{l}\text { Almost } \\
\text { fully } \\
\text { correlated }\end{array}$ \\
\hline
\end{tabular}




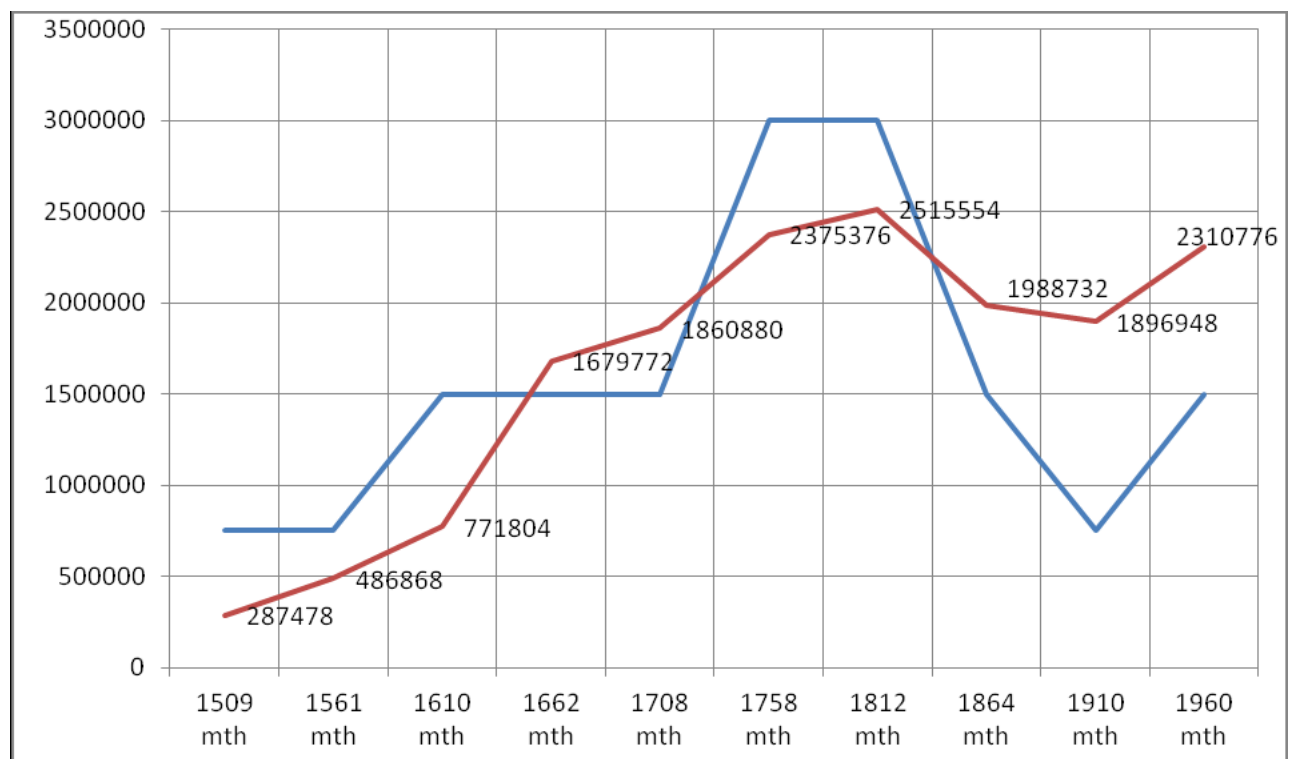

Fig. 6 The graph shows the number of solid particles in oil according to ISO 4406: 1999 and NAS 1638 in relation to the work progress of the Claas Axion 5000 farm tractor. Blue line - Average amount of particles $>4 \mu \mathrm{m}$ according to the ISO standard. Red line - summed average number of solid particles above $2 \mathrm{~mm}$ in size according to NAS standard.

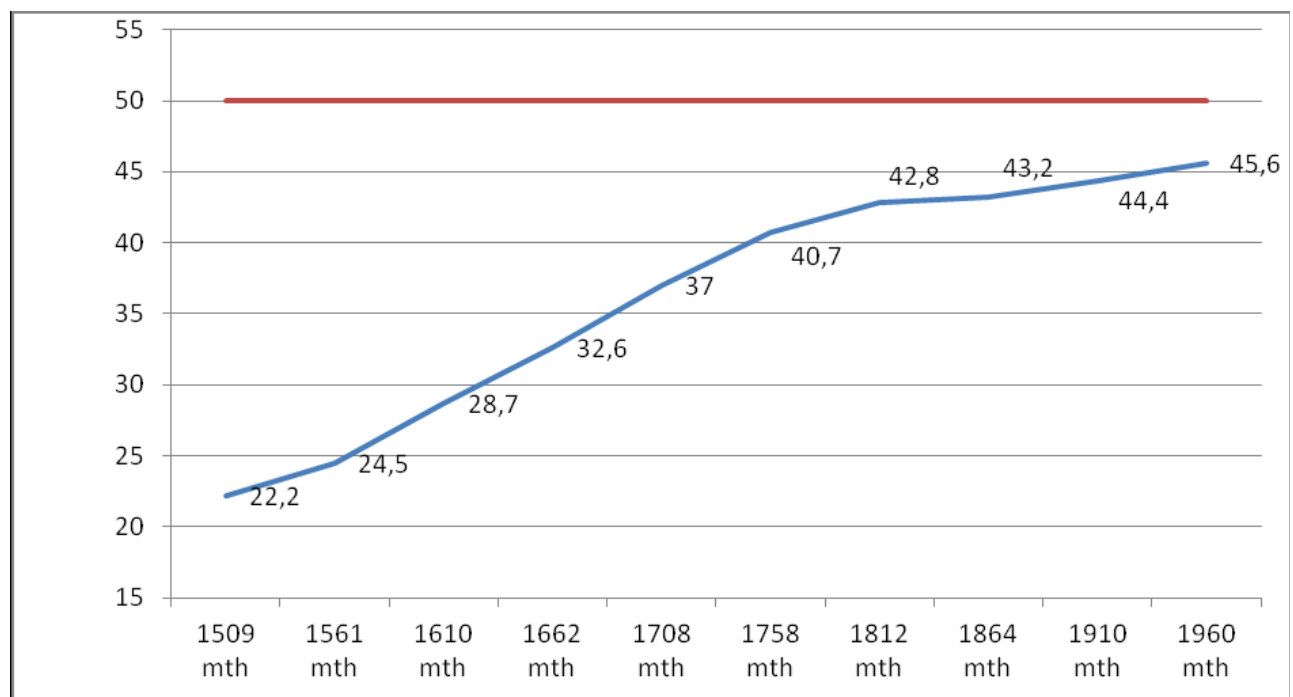

Fig. 7. Presentation of the percentage of water in oil in relation to the safe level of saturation and work progress of the agricultural tractor Claas Axion 5000. Blue line - average percentage of water content [\%]. Red line - safe level of water saturation in oil (less than $50 \%$ ). 
Table 4. Analysis of the test results of the JCB 535-95 telehandler in terms of the condition of the spray liquid, and the course of work - Pearson's correlation coefficient.

\begin{tabular}{|c|c|c|c|c|c|}
\hline No & $\begin{array}{c}\text { Workflow } \\
\text { [mth] }\end{array}$ & $\begin{array}{l}\text { Average amount } \\
\text { of particles }> \\
4 \mu \mathrm{m} \text { according to } \\
\text { the ISO standard }\end{array}$ & $\begin{array}{l}\text { Average amount } \\
\text { of particles }>2 \\
\mu \mathrm{m} \text { according to } \\
\text { the NAS standard }\end{array}$ & & $\begin{array}{l}\text { verage } \\
\text { entage of } \\
\text { r content } \\
{[\%]}\end{array}$ \\
\hline 1 & 4500 & 750000 & 646230 & & 22,1 \\
\hline 2 & 4550 & 750000 & 712874 & & 25,1 \\
\hline 3 & 4601 & 750000 & 842048 & & 29,3 \\
\hline 4 & 4649 & 750000 & 926912 & & 34,2 \\
\hline 5 & 4701 & 1500000 & 1422176 & & 40,1 \\
\hline 6 & 4751 & 1500000 & 1714204 & & 48,5 \\
\hline 7 & 4803 & 3000000 & 2259152 & & 61,7 \\
\hline 8 & 4854 & 3000000 & 1824648 & & 69,8 \\
\hline 9 & 4901 & 3000000 & 2187576 & & 78,3 \\
\hline 10 & 4952 & 3000000 & 2335984 & & 84,1 \\
\hline \multirow{2}{*}{\multicolumn{2}{|c|}{$\begin{array}{l}\text { Pearson's } \\
\text { correlation } \\
\text { coefficient }\end{array}$}} & \multicolumn{2}{|c|}{$\begin{array}{c}\text { Dependence between the course of the } \\
\text { object's operation and the amount of } \\
\text { solid particles }>2 \mu \mathrm{m} \text { according to the } \\
\text { NAS standard }\end{array}$} & .96 & $\begin{array}{l}\text { Almost } \\
\text { fully } \\
\text { correlated }\end{array}$ \\
\hline & & \multicolumn{2}{|c|}{$\begin{array}{l}\text { The dependence between the course of } \\
\text { the object's operation and the percentage } \\
\text { of water content. }\end{array}$} & .99 & $\begin{array}{l}\text { Almost } \\
\text { fully } \\
\text { correlated }\end{array}$ \\
\hline
\end{tabular}

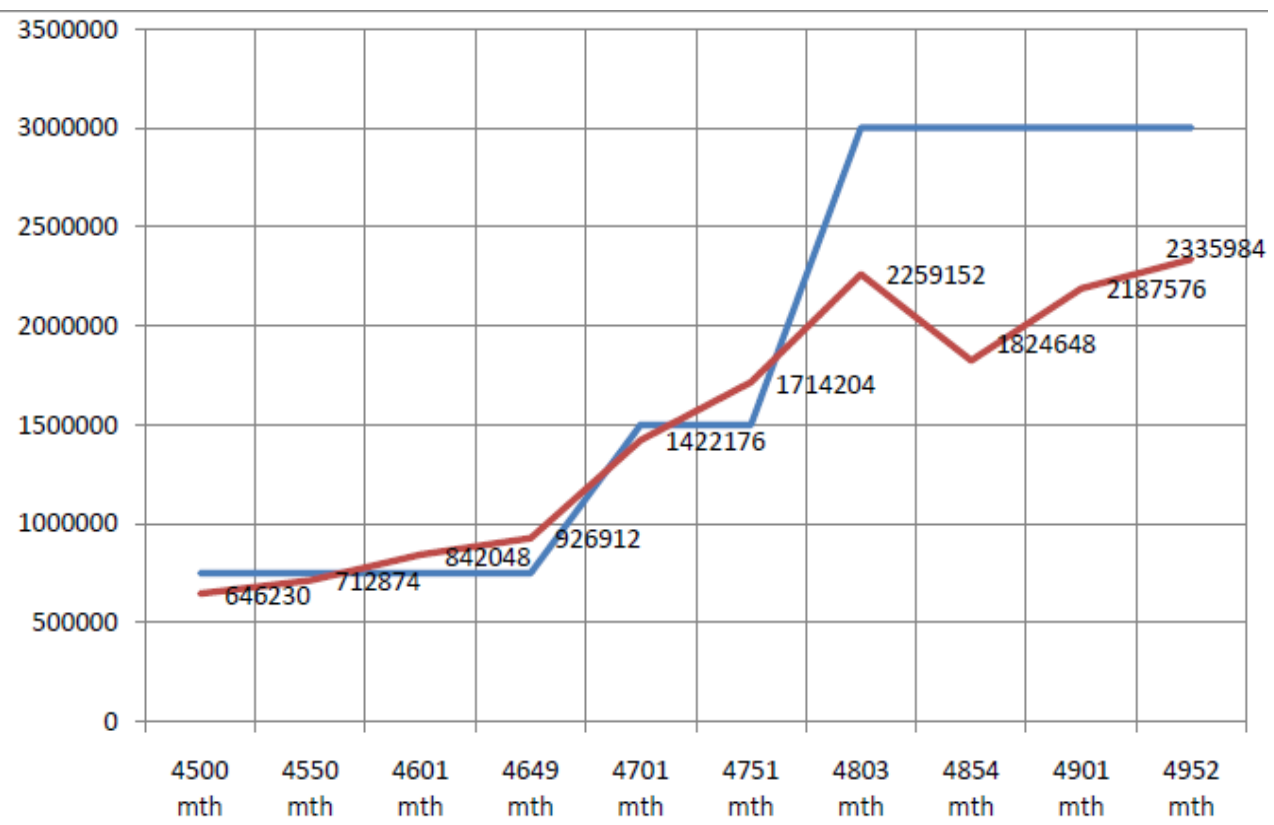

Fig. 8 The graph shows the number of solid particles in oil according to ISO 4406: 1999 and NAS 1638 in relation to the work progress of the JCB 535-95 telehandler. Blue line - Average amount of particles $>4 \mu \mathrm{m}$ according to the ISO standard. Red line - summed average number of solid particles above $2 \mathrm{~mm}$ in size according to NAS standard. 


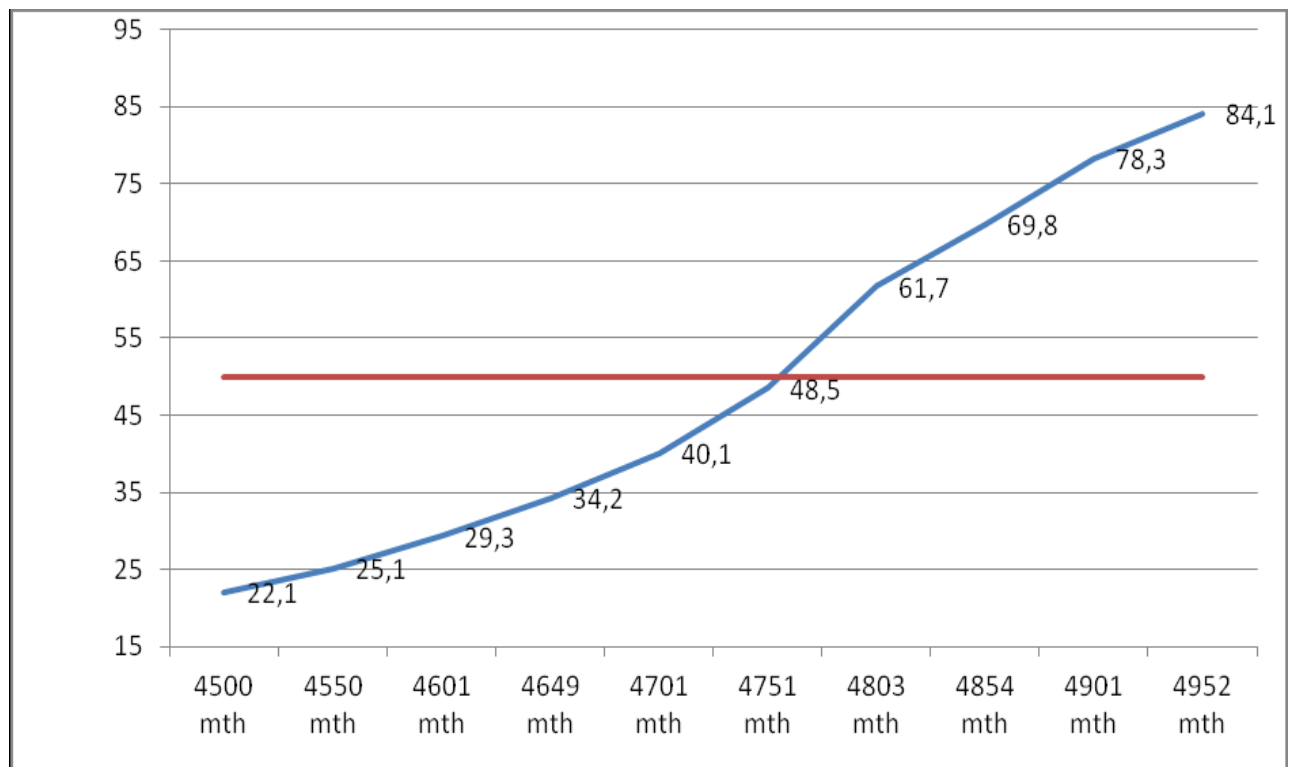

Fig. 9. Presentation of the percentage of water in oil in relation to the safe level of saturation and work progress of the JCB 535-95 telehandler. Blue line - average percentage of water content [\%]. Red line - safe level of water saturation in oil (less than $50 \%$ ).

\section{Conclusions}

The measurements for each sample indicate that they were made correctly, which confirms the value of the standard deviation within the limits of unity. Also the number of measurements allows for correct interpretation of the results for each sample.

The values of particulate pollution and the percentage of water content are different for each object. This is mainly due to the operating conditions and the construction and specifications of the hydraulic system. The Claas Axion 830 agricultural tractor was operated under favorable operating conditions, but due to the complex hydraulic system with the transmission system, a significant impact on the greater amount of particulate matter contamination was observed compared to the other hydraulic systems.

The Claas Xerion 5000 agricultural tractor has tougher conditions of use compared to the Claas Axion 830 tractor, but its hydraulic oil supplies only one hydraulic system, which translates into results related to the amount of particulate matter.

Hydraulic system of the JCB 535-95 telehandler has a large amount of contaminants, especially the percentage of the water content, due to poor operating conditions. The water content also results from the working conditions of the machine, because the system works in the environment with a lot of live animals every day, where the humidity is high and there are significant temperature differences. For example, during the winter period, the hydraulic system works in a building where the temperature is within $20^{\circ} \mathrm{C}$, then the agricultural machine leaves the building where the temperature reaches $-15^{\circ} \mathrm{C}$, which significantly affects the condensation of the water on the walls, e.g. hydraulic tank. However, the fact that the hydraulic system has comparable amounts of contamination with solid particles to a similar system of the Claas Xerion 5000 farm tractor suggests that the hydraulic systems exploitation conditions have a large influence on their amount. By altering the exploitation conditions of the hydraulic systems, one can reduce the amount of solid particles, which in turn will impact the life of the system.

Thanks to Pearson's correlation coefficient, it has been proven that in most cases the amount of particulate contamination and the percentage of water content is also important for the system operation. The only case where the correlation between the amount of 
particulate matter and the course of work was weak the hydraulic system of the Claas Axion 830 farm tractor. This effect might have been influenced by the fact that the hydraulic oil also fed the transmission system, which shook the test results of this object.

\section{References}

1. T. Bujak, Równokołowe 520 KM. Rolniczy Przegląd Techniczny, nr 1/2015, Agencja Promocji Rolnictwa i Agrobiznesu APRA Sp. z o.o., Bydgoszcz 2015.

2. P. Drogosz, Ocena zużycia oleju hydraulicznego $w$ urzadzeniach pracujacych $w$ matych przedsiębiorstwach,. Hydraulika i Pneumatyka, $\mathrm{nr} 3 / 2009$, Oficyna Wydawnicza SIMP, Wrocław 2009.

3. K. Klarecki, Możliwości zwiększania sprawności napędów hydraulicznych. Hydraulika i Pneumatyka, nr 5/2014, Oficyna Wydawnicza SIMP, Wrocław 2014.

4. Kostek R., Landowski B., Muślewski Ł.: Simulation of rolling bearing vibration in diagnostics. Journal of Vibroengineering 2015, volume 17, issue 8, pp. 4268-4278, ISSN 1392-8716.

5. G. Kotnis, Budowa i eksploatacja układów hydraulicznych w maszynach. wyd. KaBe, Krosno 2011.

6. M.Matuszewski., T.Mikołoajczyk, D.YU.Pimenov, M.Styp-Rekowski, Influence of structure isotropy of machined surface on the wear process. International Journal of Advanced Manufacturing Technology, 2017.

7. P. Rybacki, Oleje do silnika, przektadni $i$ hydrauliki. Top Agrar Polska, nr 7/2011, Polskie Wydawnictwo Rolnicze Sp. z o.o., Poznań 2011.

8. W. Sieradzki, M. Jastrzębski M, Wpływ zanieczyszczeń stałych $i$ wody na prace urządzeń górniczych. Hydraulika i Pneumatyka, nr 2/ 2013, Oficyna Wydawnicza SIMP, Wrocław 2013.

9. A. Skrobacki, A. Ekielski: Pojazdy i ciagniki rolnicze. Wydawnictwo „Wieś Jutra",Warszawa 2012.

10. Z. Szydelski, Pojazdy samochodowe. Napęd i sterowanie hydrauliczne. Wydawnictwa Komunikacji i Łączności, Warszawa 1999.

11. The Drive \& Control Company: Hydrostatyczny napęd wentylatora firmy Bosch Rexroth $w$ pojazdach $i$ maszynach samobieżnych. Hydraulika i Pneumatyka, nr 2/2014, Oficyna Wydawnicza SIMP, Wrocław 2014.

12. The Drive \& Control Company: Nowoczesne pompy hydrauliczne o stałej i zmiennej wydajności. Hydraulika i Pneumatyka, nr 2/2015, Oficyna Wydawnicza SIMP, Wrocław 2015.

13. Z. Trela, Monitorowanie stanu oleju $w$ diagnozowaniu układów hydraulicznych. Hydraulika i Pneumatyka, nr 1/2009, Oficyna Wydawnicza SIMP, Wrocław 2009.

14. W. Zwierzycki Oleje, paliwa i smary dla motoryzacji i przemystu. Wydawnictwo i Zakład Poligrafii Instytutu Technologii Eksploatacji w Radomiu, Gorlicach 2001.

15. https://www.hydac.com (15.03.2017). 